\title{
Municipal solid waste management during COVID-19 pandemic: effects and repercussions
}

\author{
Mahmood Yousefi $^{1} \cdot$ Vahide Oskoei $^{2} \cdot$ Ahmad Jonidi Jafari $^{1,3} \cdot$ Mahdi Farzadkia $^{1,3} \cdot$ Masoumeh Hasham Firooz $^{1} \cdot$ \\ Behnaz Abdollahinejad ${ }^{1} \cdot$ Javavd Torkashvand ${ }^{1,3}$
}

Received: 16 February 2021 / Accepted: 27 April 2021 / Published online: 3 May 2021

(C) The Author(s), under exclusive licence to Springer-Verlag GmbH Germany, part of Springer Nature 2021

\begin{abstract}
The COVID-19 pandemic has an adverse effect on the environment. This epidemic's effect on the waste composition and management and the impacts of municipal solid waste management (MSWM) on disease transmission or controlling are considered a compelling experience of living in the COVID-19 pandemic that can effectively control the process. This systematic review research was conducted to determine the effects of COVID-19 on the quantity of waste and MSWM. Searches were conducted in three databases (using keywords covid 19, coronaviruses, and waste), and among the published articles from 2019 to 2021,56 ones were selected containing information on the quantity and waste management during the COVID-19 pandemic. The results showed that COVID-19 caused the quantity variation and composition change of MSW. COVID-19 also has significant effects on waste recycling, medical waste management, quantity, and littered waste composition. On the other hand, the COVID-19 pandemic has changed waste compounds' management activities and waste generation sources. Recognizing these issues can help plan MSWM more efficiently and reduce virus transmission risk through waste.
\end{abstract}

Keywords COVID-19 $\cdot$ Solid waste management $\cdot$ Pandemic $\cdot$ Medical waste

\section{Introduction}

From the Betacoronavirus sub-genus, the Coronavirus is the cause of a respiratory disease known as COVID-19, first discovered in Wuhan, China, in December 2019 (Gholipour et al. 2021; Gholipour et al. 2020). The disease emerged to spread away from China in most continents and countries in less than a few months and form a global pandemic (Carraturo et al. 2020; Peng et al. 2020). This is not the first time in the last two decades that respiratory disease has spread in some parts of the country; in fact, this viral disease was the third disease in this

Responsible Editor: Philippe Garrigues

Javavd Torkashvand

torkashvand.j@iums.ac.ir; javad.torkashvand@yahoo.com

1 Department of Environmental Health Engineering, School of Public Health, Iran University of Medical Sciences, Tehran, Iran

2 Department of Environmental Health Engineering, School of Public Health, Tehran University of Medical Sciences, Tehran, Iran

3 Research Center for Environmental Health Technology, Iran University of Medical Sciences, Tehran, Iran group that has spread after severe acute respiratory syndrome (SARS) coronavirus in 2002 and the Middle East respiratory syndrome coronavirus (MERS) in 2012 (Wang et al. 2020). The critical difference between COVID-19 and the previous two diseases is that its transmission has a high attack rate, spreading rapidly worldwide. The coronavirus outbreak has severely affected both human beings' individual and social aspects by widespread changes in daily life. The coronavirus pandemic has possessed overwhelming effects on municipal solid waste management (MSWM) and affected the waste in quantity and characteristics (Di Maria et al. 2020; Nzediegwu and Chang 2020; Peng et al. 2020). Possible ways of transmitting infectious diseases such as coronavirus through household waste in situations where the infected or suspected person is being treated or cared for at home are touching contaminated surfaces and objects during household waste management and the possibility of produced aerosol during waste handling (Di Maria et al. 2020). With the pandemic's effects on the quantity and components of municipal solid waste (MSW), it is necessary to define MSWM priorities and adapt programs to the new conditions by considering these preferences. The priorities set by the International Solid Waste Association for MSWM during COVID-19 can be a good model. This 
association has identified three priorities for waste management activities as follows (Mavropoulos et al. 2014):

(A) Ensuring the continuity of waste management services, recycling, disinfection, and final disposal of MSW in pandemic conditions to prevent increased risk to society caused by inefficient MSWM. In this situation, waste service personnel, especially the collection department, must take reasonable precautions and safety tips against disease transmission during MSWM.

(B) Adaptation of recycling activities considers the existing conditions for controlling and preventing the spread of disease.

(C) Increasing the capacity of medical and infectious waste management in the stages of collection to disinfection and disposal to ensure the non-transmission of infection and contamination.

It is necessary to adapt the activities to the new conditions to achieve MSWM priorities in the pandemic situation. One of the essential requirements for adapting waste management activities in pandemic conditions is recognizing its effects on municipal solid waste and various management stages. This systematic review research aimed to identify the impact of the COVID-19 pandemic on numerous aspects of the quantity and management of municipal solid waste. All of COVID-19's published articles were reviewed to achieve this goal with both titles of municipal solid waste quantity and/or municipal solid waste management status.

\section{Methods}

\section{Search of literature}

In this review, the authors searched three databases, including Scopus, PubMed, and Web of Science, about COVID-19's impact on waste management and find related articles according to the study's objectives. The two types of search terms included "COVID-19 and coronaviruses" as the first and "waste" as the second. The search protocol was defined based on one of the first items, and waste had to appear in the titleabstract-keyword and the keywords. In the search phase, the time limitation for publishing the article in 2019 and 2021 was selected.

\section{Eligibility criteria}

The literature was screened independently by all the authors, and in the case of conflicting decisions over the initial screening, the respective study was included in the next step of screening. The final articles were selected based on municipal solid waste management's eligibility criteria during the
COVID-19 pandemic. Therefore, articles that had one of the following criteria were selected for this study:

1. Quantitative assessment of municipal solid waste during the COVID-19 pandemic

2. Study of municipal solid waste management during the COVID-19 pandemic

3. Study of medical waste management during the COVID19 pandemic

4. Information on executive changes in waste management during the COVID-19 pandemic

5. Presenting the evidence and findings that illustrated changes caused by the COVID-19 pandemic in the composition and quantity of different municipal solid waste components

\section{Study selection}

The literature was screened independently according to the mentioned criteria by the authors. In the first step, all related articles to the COVID-19 pandemic by the title of municipal solid waste or the environment were selected. In the case of conflicting decisions over the initial screening, excluded articles were reviewed by all authors. The articles on solid waste about the COVID-19 pandemic were selected in the second screening stage by studying papers' abstracts. Finally, in the third stage of screening, by reviewing the previously selected items' text, 56 related articles were selected (Fig. 1).

\section{Identification}

Records after duplicates removed $(\mathrm{n}=891)$

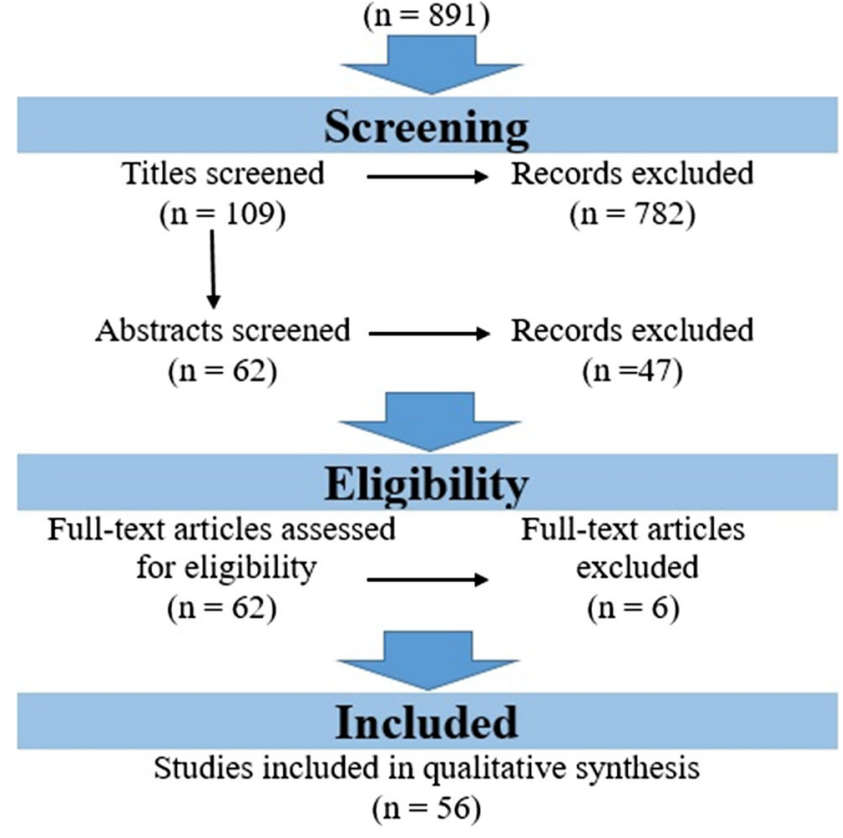

Fig. 1 The screening process to make a shortlist for this study 


\section{Results and discussion}

\section{The impact of the COVID-19 pandemic on the quantity and composition of municipal solid waste}

An essential effect of disease outbreaks is the rapid change of the quantity and composition of municipal solid waste, which is evident in the COVID-19 pandemic (Klemeš et al. 2020; Nzeadibe and Ejike-Alieji 2020). This change is created due to two crucial reasons: first, in the pandemic situation, the lifestyle will change according to the created conditions; second, the community's health needs will increase production and consumption rates in some specific parts, which play a key role in changing of the composition and quantity of municipal solid waste.

The COVID-19 pandemic effects on different waste components have not been the same, such a way that the pandemic has reduced waste production in some areas and pervasively disrupted plastic consumption reduction policies (Liang et al. 2021). The generated plastic wastes since the COVID-19 outbreak are considered at 1.6 million tonnes/day globally. Almost 3.4 billion single-use face masks and shields were discarded daily (Benson et al. 2021a). In the meantime, the COVID-19's PCRs were responsible for generating 15,000 tons of plastic that were incinerated by $97 \%$ (Celis et al. 2021). For instance, a significant rise in plastic and fiberbased municipal solid waste materials is evident due to the widespread use of face masks and disposable gloves and other personal protection equipment (PPE) during the COVID-19 pandemic (Klemeš et al. 2020). Also, lifestyle changes, especially the provision of daily necessities, such as the widespread use of home delivery services, have raised paper and plastic waste from packaging. These changes and the increase in the ratio of using home food to ready meals in the community have caused some societies to face an increase in municipal solid waste (Dente and Hashimoto 2020; ZambranoMonserrate et al. 2020). Increased plastic consumption due to its high capability to produce masks and disposable gloves (Dente and Hashimoto 2020; Klemeš et al. 2020) and the packaging of health products and goods delivery in homes and consumption places are evident. In some cases, especially in the initial outbreaks of the COVID-19, an increase in online shopping has led to a rise in disposable products because of decreased daily activities (Rhee 2020). Also, food delivery services during the COVID-19 pandemic increased, which lead to the raising of plastic packaging and food waste (household waste) (Leal Filho et al. 2021). Increased in-home cooking led to raising household waste generation in some countries due to concerns about virus transmission through ready-to-eat foods (Dente and Hashimoto 2020). During this pandemic, the awareness of younger generations about food waste increased (Burlea-Schiopoiu et al. 2021).
The generation of food waste ratio to the municipal solid waste changed in these conditions, increasing by $12 \%$ in Spain. Nevertheless, saving food and avoiding food waste can reduce this waste generation due to concerns about the pandemic's economic consequences on the family dimension, as seen in the first 2 weeks of the COVID-19 in Tunisia (Jribi et al. 2020). In contrast, food waste production in Italy and the USA has decreased due to the greater tendency to prepare more home-cooked meals and living away from supermarkets (Rodgers et al. 2021). Also, the coronavirus pandemic has directly affected municipal solid waste composition by increasing the volume of non-recyclable waste and indirectly increasing organic waste generation through trade disruption due to reduced agricultural and fishery exports (Cheval et al. 2020). However, unlike household waste, industrial waste generation may decrease due to the disruption of industrial activities and goods trade during the pandemic (Dente and Hashimoto 2020). These conditions will not be the same everywhere due to geographical location, lifestyle, and the extent of the disease's impact on daily activities. In some cases, it may reduce the rate of municipal solid waste generation in pandemic conditions. For example, the related research to the coronavirus pandemic (China) has indicated that waste generation in large- and medium-sized cities in China has decreased by up to 30 percent. In contrast, medical waste has been generated several times in these cities, so that in Wuhan, this increase has been reported up to six times (Klemeš et al. 2020). However, in some countries like Italy, epidemiology and health policy recommend utilizing single-use disposable plates in restaurants and cafes, resulting in an increased municipal solid waste generation (Zambrano-Monserrate et al. 2020). Therefore, waste quantity changes and component ratios have shocking effects on efficient waste management systems. It is necessary to adapt programs with these existing conditions to determine the quantity and composition of municipal solid waste based on society's behavior changes and redefining municipal solid waste management. Management changes may be accompanied by creating new methods for some municipal solid waste, as exemplified in the South Korean model for the separate administration of masks and disposable gloves in the coronavirus pandemic (Rhee 2020). The inquiry illustrated the requirements of short-, mid-, and longer-term responses to waste management in the pandemic situation (Hantoko et al. 2021).

\section{The impact of the coronavirus pandemic on the waste management process}

Infectious disease outbreaks and their transmission concerns through municipal solid waste caused the change in the waste management based on past experiences or gained experiences in other countries, so some previous processes stopped or resumed with significant differences in defined requirements. 
The most important reason for such a behavioral change is to prevent the transmission of pollution from waste contaminated (or suspected to be infected) and reducing the likelihood of disease transmission. For example, a compactor waste collection vehicle for household waste may be set aside for extra caution because of concerns about the virus's spread to the air (Mol and Caldas 2020). In this case, trucks, human resources, and more costs will be needed for waste management. The most important part of waste management affected by these changes is waste recycling, so in a pandemic situation, municipal solid waste recycling is expected to decrease significantly. There is evidence of a decline of the waste-to-material industry in the COVID-19 epidemic compared to the previous period (Zhou et al. 2021). Examples include banning or restricting municipal solid waste recycling centers in the USA and Europe during the coronavirus pandemic due to concerns about the virus's spread (Zambrano-Monserrate et al. 2020). Separation of household waste was also prohibited in countries such as Italy, where a suspected or infected person is isolated or cared for at home, which will reduce the entry of recyclable waste into the reuse cycle (Zambrano-Monserrate et al. 2020). These conditions have led to concerns about reduced waste recycling and its environmental consequences during the pandemic (Kahlert and Bening 2020). In developing countries, the recycling sector relies on separation at the disposal stage and landfills done by waste pickers (informal sector). In this section, changing the situation is very complicated and impossible. Therefore, the disease transmission risk of poor waste management is expected to be higher in developing countries than in developed ones (Nzediegwu and Chang 2020). So, close attention to waste collection and management programs is necessary for slums and refugee camps to deal with COVID-19 (Corburn et al. 2020). Thus, municipal waste management systems need to activate or improve the quality of services in these areas to prevent disease spread in the community, requiring spending more money and using equipment and human resources. On the other hand, the disease outbreak and quarantine regulations can cause citizens to move from the primary residence to their secondary settlements, which may put pressure on the capacity of rural waste management (Dente and Hashimoto 2020), so the ability of the waste management system in this areas must be increased in terms of equipment and staff.

In some cases, a pandemic has affected urban waste management. For instance, the disposal of the face masks and plastic gloves in Isfahanian has increased to over 1.49 and 2.98 million pieces which harm the disruption of waste compost, and landfilling becomes 3.6 times more than before the COVID-19 pandemic (Zand and Heir 2021b). Also, the amount of urban waste landfills in Tehran has increased by 35\% (Zand and Heir 2021a).

This situation has led to improvement in the waste management system due to the health protocols. The municipal waste incineration plants' operation temperature has raised to wipe out viruses adequately because of the possibility of mixing urban waste with medical waste (Tsai 2021). Therefore, it is necessary paying more attention to the waste management pandemic conditions' guidelines to reduce the damage caused by poor waste management (Torkashvand et al. 2021).

One of the most important effects of the pandemic is seen in the management of medical waste. Concerns are raised around the spread of the coronavirus through medical waste, which itself led to the adoption of separate pathways for storage, collecting, and transporting this possibly contaminated waste. For example, it is recommended that medical waste and household waste from clinics, isolated sections, unique examination rooms, and medical laboratories, especially nucleic acid testing laboratories, be considered and managed as COVID-19-related medical waste (Peng et al. 2020). A Chinese hospital report said that for controlling the pandemic better and reducing the risk of transmitting the virus, the sanitary landfill method was replaced by the waste incineration method. Also, the storage of coronavirus-related medical waste was decreased from 48 to $24 \mathrm{~h}$, and all infectious and household waste in hospitals should be incinerated in a short time (Peng et al. 2020).

\section{Impact of the coronavirus pandemic on littered waste}

Litter referred to waste products that have been disposed of inaccurately by people at the wrong location. Numerous studies have been conducted on the quantity and composition of litter in various regions, such as beaches, showing that plastic compounds and cigarette butts are abundant littered items (Gholami et al. 2020). However, an essential concern is the disposal of potentially contaminated litter in public places and the environment. The use of PPE, such as face masks and gloves, is one of the most critical health recommendations in the coronavirus pandemic. Still, this equipment's inappropriate disposal by citizens is considered the essential concern of many countries. The conducted studies in the USA illustrated that the widespread use of masks and gloves play a crucial role in increasing litter (Zambrano-Monserrate et al. 2020); moreover, there is also evidence in Spain and Asia of the transfer of used masks to water areas and an increase in the number of disposable masks and gloves discarded on beaches (Fadare and Okoffo 2020; Saadat et al. 2020). Discarded masks on the South American coast has been considered a concern. Textile fibers impregnated with $\mathrm{Ag}^{+} / \mathrm{Cu}^{2+}$ nanoparticles have long-term effects on the aqueous environment (Ardusso et al. 2021). A study showed that face masks are the most common personal protective equipment pilling up on the beaches during the pandemic, which has increased during the time (De-laTorre et al. 2021). The discarded face masks in African countries are estimated at 12 billion per month (around 105,000 
tonnes of infected waste per month) (Benson et al. 2021b). These conditions are not limited to beaches, and riverine debris has increased in Jakarta in the COVID-19 pandemic. Mask was the most abundant kind of plastics, which accounted for about $16 \%$ of the total riverine debris (Cordova et al. 2021). The results of a study in Toronto, Canada, found that disposable gloves and face mask accounted for about $44 \%$ and $31 \%$ of debris related to personal protective equipment, which is known as a new source of plastic pollution (Ammendolia et al. 2021). Another Kenyan study illustrated that up to $16.5 \%$ of the total litter experienced in the streets is related to the COVID-19 items, while litter associated with COVID-19 was not found on recreational beaches (Okuku et al. 2021).

However, the travel and tourism industry's decline has positively affected reducing litter in recreational places such as beaches. The increasing use of masks and gloves has led to the rise in urban litter (Kalina and Tilley 2020), which requires proper management due to the possibility of their contamination. Littering pandemic-related waste is a major environmental concern and increases the likelihood of the disease spreading through municipal solid waste. Since most masks and protective gloves against coronavirus are made of plasticbased materials, the presence of these materials in the environment can be considered a microplastic source (Fadare and Okoffo 2020). Discarded face masks, because they are made of oil-derived polymers, can be an important source of pollution for marine environments by releasing large tonnes of microplastics (Dharmaraj et al. 2021a). The outcomes illustrated that single-use face masks could be the dye carrier in the aquatic environment (methylene blue, crystal violet, and malachite green). Although the pandemic outbreak can positively affect the reduction of urban litter due to the decrease in population density in public areas, the rise in the proportion of infectious or suspected litter can provide a higher risk factor for disease transmission and public health threats through municipal solid waste (Table 1).

Therefore, it is necessary to find a solution for waste management associated with COVID-19, especially face masks. Degradation and crushing of discarded masks were essential for pavement applications and considered a solution to control the large volume of waste (Saberian et al. 2021). Also, alternative materials for making face masks can reduce the environmental damage caused by the COVID-19 pandemic (Hartanto and Mayasari 2021).

\section{Coronavirus impacts on the health of municipal solid waste management employees (MSWEs)}

Waste management is one of the constant needs of a society that must be done daily and without interruption. The workforce is one of the essential municipal solid waste management needs from collection to final disposal, making their
Table 1 Effects of epidemics on the quantity and composition of municipal solid waste and litters in summary

\begin{tabular}{|c|c|c|}
\hline Issue & Remarks & Ref. \\
\hline $\begin{array}{l}\text { Waste } \\
\text { quantity }\end{array}$ & $\begin{array}{l}\checkmark \text { Sharp changes in the solid } \\
\text { waste quantity and } \\
\text { composition due to both } \\
\text { crucial reasons: firstly, the } \\
\text { lifestyle changes; secondly, } \\
\text { the community's health } \\
\text { needs will increase } \\
\checkmark \text { Significant rise in plastic- } \\
\text { and fiber-based municipal } \\
\text { solid waste materials due to } \\
\text { the widespread use of PPE, } \\
\text { single-use dish or cup, and } \\
\text { also home delivery services } \\
\checkmark \text { An increase in the ratio of } \\
\text { using home food caused } \\
\text { some societies to face an } \\
\text { increase in municipal solid } \\
\text { waste } \\
\checkmark \text { Industrial waste generation } \\
\text { may decrease during the } \\
\text { COVID-19 } \\
\checkmark \text { In some cases, it may reduce } \\
\text { the rate of municipal solid } \\
\text { waste generation in } \\
\text { pandemic conditions }\end{array}$ & $\begin{array}{l}\text { Dente and Hashimoto (2020); } \\
\text { Klemeš et al. (2020); } \\
\text { Nzeadibe and Ejike-Alieji } \\
\text { (2020); } \\
\text { Zambrano-Monserrate et al. } \\
(2020)\end{array}$ \\
\hline $\begin{array}{l}\text { Waste } \\
\text { composi- } \\
\text { tion }\end{array}$ & $\begin{array}{l}\checkmark \text { The food waste ratio to the } \\
\text { municipal solid waste } \\
\text { changed during the } \\
\text { COVID-19 } \\
\checkmark \text { Increasing the volume of } \\
\text { non-recyclable waste and } \\
\text { increasing organic waste } \\
\text { generation }\end{array}$ & $\begin{array}{l}\text { Cheval et al. (2020); Dente } \\
\text { and Hashimoto (2020); Jribi } \\
\text { et al. (2020) }\end{array}$ \\
\hline $\begin{array}{l}\text { Littered } \\
\text { waste }\end{array}$ & $\begin{array}{l}\checkmark \text { Inappropriate disposal of } \\
\text { PPE by citizens is } \\
\text { considered an essential } \\
\text { concern } \\
\checkmark \text { Increase in the number of } \\
\text { disposable masks and } \\
\text { gloves discarded on } \\
\text { beaches } \\
\checkmark \text { The travel and tourism } \\
\text { industry's decline can lead } \\
\text { to reducing litter in } \\
\text { recreational places, but } \\
\text { increasing use of PPE has } \\
\text { led to the rise in the urban } \\
\text { litter } \\
\checkmark \text { COVID-19 can positively } \\
\text { affect the reduction of urban } \\
\text { litter due to the decrease in } \\
\text { population density in public } \\
\text { areas }\end{array}$ & $\begin{array}{l}\text { Fadare and Okoffo (2020); } \\
\text { Kalina and Tilley (2020); } \\
\text { Saadat et al. (2020); } \\
\text { Zambrano-Monserrate et al. } \\
\text { (2020) }\end{array}$ \\
\hline
\end{tabular}

presence the necessary sector for providing municipal services. Health workers, caseworkers, waste pickers, and municipal workers are among the high-risk occupations in the COVID-19 war (Behera 2021). For this reason, waste collectors can mediate the transmission of disease from medical waste to the community (Das et al. 2021). So, concerns about 
the possibility of disease transmission through municipal solid waste should be taken more seriously. Although there is no credible evidence about coronavirus transmission through waste, there is still a concern for transmitting this virus to MSWEs, especially in waste pickers (informal sector). In many cases, they also do not use adequate PPE (Di Maria et al. 2020). Up until now, there are no confirmed COVID19 cases of disease transmission through contact by municipal solid waste, but it is a potential threat to MSWEs according to the stability of COVID-19 on various surfaces (differed from several hours to days depending on environmental conditions) (Di Maria et al. 2020; Hale and Song 2020; Mol and Caldas 2020), its resistance to ultraviolet radiation, and the transmission through contaminated gloves, masks, and water and beverage bottles. Therefore, inefficient waste management may cause a severe threat to the informal waste collector workers. Accordingly, international organizations provided guidelines for the workforce employed in municipal solid waste management in many developed countries. Therefore, considering the recovery period of coronavirus and the need to observe a 14day self-quarantine of suspected people, special attention is necessary to maintain workers' health and continue waste management activities.

\section{Coronavirus impacts on policies and attitudes of waste management}

The attitudes and policies of municipal waste management can be affected due to the coronavirus pandemic. These attitude and quick action will follow the needs and ensure the minimization of disease transmission through waste management and effectively protect waste employees' health. Policy changes in parts of municipal waste management should lead to changes in activities at the waste generators. These activities are necessary due to the virus's presence in the waste or a precautionary measure due to the possibility of the virus's presence. For instance, household waste management is necessary when self-isolation and home care are prescribed for patients with mild clinical symptomatology. When a sick or suspicious person is cared for at home, the generated waste requires special attention and superior management (Di Maria et al. 2020), which should be managed separately from other houses' household waste (Klemeš et al. 2020; ZambranoMonserrate et al. 2020). This change in household waste management is a necessity during the pandemic.

In some cases, if there is a possibility of the disease causative agent in the municipal solid waste, a behavior change will be observed due to changes in the waste classification. A good example is changing attitudes about food waste in Germany, which was formally defined as regular waste, while during the coronavirus pandemic, they are defined and managed as hazardous waste (Klemeš et al. 2020). On the other hand, industries, factories, and people have not adhered to the ban of using disposable bags during the pandemic and have sometimes even been persuaded to utilize them (ZambranoMonserrate et al. 2020), so the possibility of coronavirus persisting on disposable plastics (plastic bags) is a severe concern that can play a role in contributing the spread of the disease. Therefore, environmental campaigns and governments attempt to ban single-use plastic during the coronavirus pandemic (Hale and Song 2020). A significant attitude as the precautions and preventive measures during the COVID-19 outbreak is that the whole medical waste must be considered infectious waste and be managed according to their criteria; an example of such a change is reported about a radiotherapy center in China (Wei et al. 2020). Therefore, in this situation, outstanding management is necessary for some municipal solid waste, which is differed from normal conditions, comprising changes in the classification of some components, management changes, and redefining the performance of waste management systems based on the new situation (Table 2).

\section{Impact of COVID-19 epidemic on medical waste}

Medical and infectious waste with exceptional management is among the most critical components of municipal solid waste, significantly increasing in quantity due to pandemic disease prevalence (Klemeš et al. 2020; Wang et al. 2020; ZambranoMonserrate et al. 2020). This type of waste increases as a result of providing a full range of healthcare services in medical centers and using PPE, which will raise the amount of infectious contamination (Klemeš et al. 2020; Wang et al. 2020; Zambrano-Monserrate et al. 2020). Significant growth in medical waste production has been reported between 18 and $425 \%$ (Liang et al. 2021). These quantity changes with the possibility of contagious contamination occur if the waste management system cannot respond to this change. So, there will be a possibility of increasing disease transmission rates due to inefficient waste management (Nzediegwu and Chang 2020; Peng et al. 2020). Infectious waste management in medical centers is not done correctly in many developing and emerging countries, which will increase the likelihood of the virus spreading; an example is reported about the low segregation rate of infectious waste in Tanzania (Powell-Jackson et al. 2020). Accordingly, improper management of healthcare waste has been identified as effective in spreading the COVID-19 virus (Das et al. 2021). However, the importance of the mentioned matter that its effects can remain vital concerning the waste management system even after the end of the pandemic is neglected due to apparent challenges in the community's health and economic sectors (Klemeš et al. 2020). Therefore, the municipal solid waste management system should possess an active reaction to the new conditions and quickly adapt its activities to these conditions.

The impact of quantity changes and increased medical and infectious waste generation sources will change the waste 


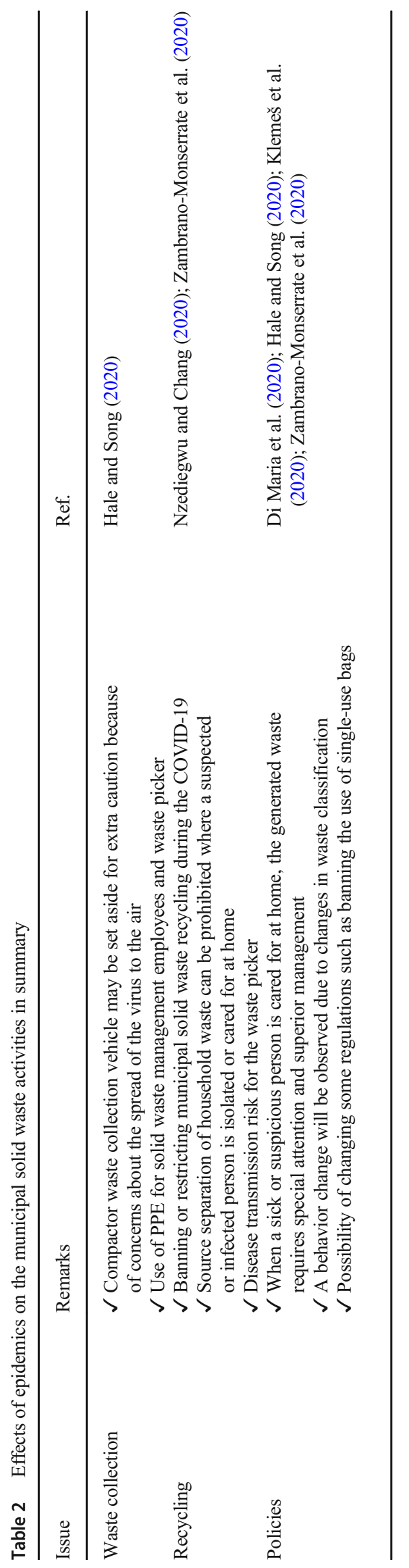

management system's performance and equipment types in the pandemic situation. In South Korea, for example, storage time was not considered for medical waste during the COVID-19 pandemic, whereas the recommended storage time in the normal situation was 7 days (Rhee 2020). The generation of infectious waste in non-hospital units is one of the problematic consequences for municipal solid waste management. In pandemic conditions, especially about the latest pandemic, self-quarantine of infected people has a crucial role in generating infectious waste at home. Besides, there are suspected patients in household quarantine, so the precautionary approach is that these homes' waste must be managed like an infectious waste (Di Maria et al. 2020; Rhee 2020).

The sharp rise in infectious and suspected waste generation and the limited capacity of on-hazardous incinerators in this situation practically create an executive challenge in medical waste management (Klemeš et al. 2020). Changing the direction of infectious and hospital waste can also be a fundamental challenge due to the daily management of medical waste without storage time (Rhee 2020). The dramatic increase in India's biomedical waste production during COVID-19 has led to guidelines for proper management of waste, including the inner and outer surface of containers should be disinfected by a $1-2 \%$ sodium hypochlorite solution daily and generated biomedical waste (BMW) related to COVID-19 must be rigidly disposed of within $24 \mathrm{~h}$ (Chand et al. 2021). It has also been reported that hospital waste increased from 17 to $61 \%$ during Tehran's pandemic (Zand and Heir 2021a). Meanwhile, the proportion of infectious waste production in hospitals has also increased (Kalantary et al. 2021).

New waste management facilities are the method of sophisticated choice for treating large volumes of the infected waste considering economic issues, emission control, legal aspects, public acceptance, and obligation in municipal solid waste management (Klemeš et al. 2020). It is possible to choose the waste disinfection method associated with COVID-19 based on criteria such as flexibility, pollutant emission, and energy balance. Among the thermochemical methods, incinerators can disinfect all waste types, but this method pollutes the air, while gasification and pyrolysis have higher efficiencies in energy balance (Purnomo et al. 2021). Pyrolysis is considered a practical technology for decomposing medical and plastic waste (Dharmaraj et al. 2021b). The use of incinerator's capacities increased by raising the amount of COVID-19-related waste in India, which ultimately increased the release of pollutants such as $\mathrm{NO}_{\mathrm{x}}, \mathrm{SO}_{\mathrm{x}}$, $\mathrm{CO}, \mathrm{Cd}$, and $\mathrm{Pb}$ into the atmosphere (Thind et al. 2021). Accordingly, considering the incinerators as the best methods for disposing healthcare waste has a challenge due to its emitted pollutants (Manupati et al. 2021).

There will be a significant difference between the medical waste generation and the disinfection equipment's capacity during the pandemic. So, the equipment's capacity must increase in proportion to the new rate of waste production. The 
maximum capacity of healthcare waste management equipment is known as the critical point. Although equipment capacity can be increased in an epidemic situation, the waste generation rate beyond the critical point is not practical. In this case, it is necessary to manage the entering waste to waste management system and adopt methods to reduce medical waste production (Klemeš et al. 2020). Attempts to disinfect and reuse masks have been considered in some studies to reduce medical waste generation (Ma et al. 2020; Perkins et al. 2020).

In these circumstances, complementary methods may be considered for medical waste management and disinfection, according to financial, technical, environmental, and even public acceptance issues (Klemeš et al. 2020).

If medical waste generation is more than the critical point, alternative medical waste management methods should be utilized. For example, an offered solution in Spain to address the shortages of incinerators' capacity was the use of the cement plant ones (Klemeš et al. 2020). However, the complementary method under the COVID-19 crisis for medical waste management is sanitary landfills, which have certain environmental aspects, especially PPE, one of the most important waste constituents. Therefore, researchers have prospered the entirely biodegradable PPE due to the landfill's limited capacity (Das et al. 2020). Therefore, the safe management of infectious and hazardous wastes related to COVID-19 requires the definition and revision of government-citizen participation models for the new conditions (Valizadeh et al. 2021).

\section{Conclusion}

Coronavirus pandemic consequences were evaluated in the field of municipal solid waste management. The municipal solid waste rose in quantity during COVID-19, although these changes do not follow the same pattern in different communities.

Two main reasons play a critical role in increasing the waste quantity during the COVID-19 pandemic: firstly, waste production due to disease prevention or treatment activities such as face masks and diagnostic kits; secondly, waste production rising due to disease effects on lifestyles such as increasing in-home cooking and online shopping.

The ever-increasing amount of medical waste during this pandemic has been reported in all inquires, such as increasing by 350,82 , and 62 percent in China, India, and Iran, respectively.

The difference in the medical waste quantity in many studies is due to local conditions, which include population density, patient ratios in the area, disease severity fluctuation over time, healthcare capacity, and COVID-19 patient admission.
The amount of littered waste has diminished due to population decline in recreational and public centers. However, improper disposal of face masks and plastic gloves has led to the viral transmission risk by microplastic sources and marine environment contamination.

The long-term mandatory self-quarantine can change people's lifestyles by encouraging them to live in secondary settlements in the countryside, so this matter can increase waste generation in rural areas.

Therefore, the COVID-19 pandemic outcomes cause that the waste management process requires changes to reduce the risk of disease transmission to employees, citizens, and the environment.

The most critical consequences of COVID-19 on waste management can be listed as follows: increasing the amount of household waste, the rise in the proportion of plastic waste generation, littered waste reduction versus the increase in the health and environmental threats of this waste type, sharp growth in the medical waste generation, infectious waste production in places other than healthcare centers ( homes with a sick or self-quarantine person), and the low ratio of disinfection equipment versus waste generation in the community.

The change in attitude includes separate household waste management when patient care at home, changing attitudes from common waste to infectious waste regarding disposable food containers, more use of disposable plastic bags, and managing all medical waste in the form of infectious waste precaution. COVID-19 has stopped or restricted processes such as recycling due to concerns about the spread of the virus. It has raised serious concerns about using conventional equipment such as compactors in garbage trucks due to fears of spreading the virus to the air. Changing the landfill methods to the incinerator to dispose of infectious waste and reducing storage time are among the reported changes in waste management due to the COVID-19 pandemic. Therefore, recognizing the repercussions of the COVID-19 pandemic on waste management can effectively increase waste management efficiency and be used as the experience to handle similar situations in the future.

Availability of data and materials All data generated or analyzed during this study are included in this published article.

Author contribution Mahmood Yousefi and Vahide Oskoei: Investigation, writing - original draft, and writing-review and editing. Ahmad Jonidi Jafari, Mahdi Farzadkia, Masoumeh Hasham Firooz, Behnaz Abdollahinejad: Writing-review and editing. Javad Torkashvand: Supervision, investigation, and writing-review and editing.

Funding The authors gratefully acknowledge the financial support given by the Research Center for Environmental Health Technology, Iran University of Medical Sciences, Tehran, Iran (Grant Number:14201). 


\section{Declarations}

Ethics approval Not applicable

Consent to participate Not applicable

Consent for publication Not applicable

Competing interests The authors declare no competing interests.

\section{References}

Ammendolia J, Saturno J, Brooks AL, Jacobs S, Jambeck JR (2021) An emerging source of plastic pollution: environmental presence of plastic personal protective equipment (PPE) debris related to COVID-19 in a metropolitan city. Environ Pollut 269:116160

Ardusso M, Forero-López A, Buzzi N, Spetter C, Fernández-Severini M (2021) COVID-19 pandemic repercussions on plastic and antiviral polymeric textile causing pollution on beaches and coasts of South America. Sci Total Environ 763:144365

Behera BC (2021) Challenges in handling COVID-19 waste and its management mechanism: a review. Environmental Nanotechnology, Monitoring and Management 15:100432

Benson NU, Bassey DE, Palanisami T (2021a) COVID pollution: impact of COVID-19 pandemic on global plastic waste footprint. Heliyon 7:e06343

Benson NU, Fred-Ahmadu OH, Bassey DE, Atayero AA (2021b) COVID-19 pandemic and emerging plastic-based personal protective equipment waste pollution and management in Africa. Journal of Environmental Chemical Engineering 9:105222

Burlea-Schiopoiu A, Ogarca RF, Barbu CM, Craciun L, Baloi IC, Mihai LS (2021) The impact of COVID-19 pandemic on food waste behaviour of young people. J Clean Prod 294:126333

Carraturo F, Del Giudice C, Morelli M, Cerullo V, Libralato G, Galdiero E, Guida M (2020) Persistence of SARS-CoV-2 in the environment and COVID-19 transmission risk from environmental matrices and surfaces. Environmental Pollution, 115010

Celis JE, Espejo W, Paredes-Osses E, Contreras SA, Chiang G, Bahamonde P (2021) Plastic residues produced with confirmatory testing for COVID-19: classification, quantification, fate, and impacts on human health. Sci Total Environ 760:144167

Chand S, Shastry C, Hiremath S, Joel JJ, Krishnabhat C, Mateti UV (2021) Updates on biomedical waste management during COVID19: the Indian scenario. Clinical Epidemiology and Global Health, 100715

Cheval S, Mihai Adamescu C, Georgiadis T, Herrnegger M, Piticar A, Legates DR (2020) Observed and potential impacts of the COVID19 pandemic on the environment. Int J Environ Res Public Health 17:4140

Corburn J, Vlahov D, Mberu B, Riley L, Caiaffa WT, Rashid SF, Ko A, Patel S, Jukur S, Martínez-Herrera E (2020) Slum health: arresting COVID-19 and improving well-being in urban informal settlements. J Urban Health:1-10

Cordova MR, Nurhati IS, Riani E, Iswari MY (2021) Unprecedented plastic-made personal protective equipment (PPE) debris in river outlets into Jakarta Bay during COVID-19 pandemic. Chemosphere 268:129360

Das O, Neisiany RE, Capezza AJ, Hedenqvist MS, Försth M, Xu Q, Jiang L, Ji D, Ramakrishna S (2020) The need for fully bio-based facemasks to counter coronavirus outbreaks: a perspective. Science of The Total Environment, 139611
Das AK, Islam N, Billah M, Sarker A (2021) COVID-19 pandemic and healthcare solid waste management strategy-a mini-review. Sci Total Environ 778:146220

De-la-Torre GE, Rakib MRJ, Pizarro-Ortega CI, Dioses-Salinas DC (2021) Occurrence of personal protective equipment (PPE) associated with the COVID-19 pandemic along the coast of Lima, Peru. Sci Total Environ 774:145774

Dente S, Hashimoto S (2020) COVID-19: a pandemic with positive and negative outcomes on resource and waste flows and stocks. Resour Conserv Recycl 161:104979

Dharmaraj S, Ashokkumar V, Hariharan S, Manibharathi A, Show PL, Chong CT, Ngamcharussrivichai C (2021a) The COVID-19 pandemic face mask waste: a blooming threat to the marine environment. Chemosphere 272:129601

Dharmaraj S, Ashokkumar V, Pandiyan R, Munawaroh HSH, Chew KW, Chen W-H, Ngamcharussrivichai C (2021b) Pyrolysis: an effective technique for degradation of COVID-19 medical wastes. Chemosphere 275:130092

Di Maria F, Beccaloni E, Bonadonna L, Cini C, Confalonieri E, La Rosa G, Milana MR, Testai E, Scaini F (2020) Minimization of spreading of SARS-CoV-2 via household waste produced by subjects affected by COVID-19 or in quarantine. Sci Total Environ 743:140803

Fadare OO, Okoffo ED (2020) Covid-19 face masks: a potential source of microplastic fibers in the environment. Sci Total Environ 737: 140279

Gholami M, Torkashvand J, Kalantari RR, Godini K, Jafari AJ, Farzadkia M (2020) Study of littered wastes in different urban land-uses: an 6 environmental status assessment. J Environ Health Sci Eng 18:915924

Gholipour S, Nikaeen M, Manesh RM, Aboutalebian S, Shamsizadeh Z, Nasri E, Mirhendi H (2020) Severe acute respiratory syndrome coronavirus 2 (SARS-CoV-2) contamination of high-touch surfaces in field settings. Biomed Environ Sci 33:925-929

Gholipour S, Mohammadi F, Nikaeen M, Shamsizadeh Z, Khazeni A, Sahbaei Z, Mousavi SM, Ghobadian M, Mirhendi H (2021) COVID-19 infection risk from exposure to aerosols of wastewater treatment plants. Chemosphere 273:129701

Hale RC, Song B (2020) Single-use plastics and COVID-19: scientific evidence and environmental regulations. Environ Sci Technol 54: 7036-7034

Hantoko D, Li X, Pariatamby A, Yoshikawa K, Horttanainen M, Yan M (2021) Challenges and practices on waste management and disposal during COVID-19 pandemic. J Environ Manag 286:112140

Hartanto BW, Mayasari DS (2021) Environmentally friendly nonmedical mask: an attempt to reduce the environmental impact from used masks during COVID 19 pandemic. Sci Total Environ 760: 144143

Jribi S, Ben Ismail H, Doggui D, Debbabi H (2020) COVID-19 virus outbreak lockdown: what impacts on household food wastage? Environ Dev Sustain 22:3939-3955

Kahlert S, Bening CR (2020) Plastics recycling after the global pandemic: resurgence or regression? Resour Conserv Recycl 160:104948

Kalantary RR, Jamshidi A, Mofrad MMG, Jafari AJ, Heidari N, Fallahizadeh S, Arani MH, Torkashvand J (2021) Effect of COVID-19 pandemic on medical waste management: a case study. J Environ Health Sci Eng. https://doi.org/10.1007/s40201-02100650-9

Kalina M, Tilley E (2020) "This is our next problem": cleaning up from the covid-19 response. Waste Manag 108:202-205

Klemeš JJ, Van Fan Y, Tan RR, Jiang P (2020) Minimising the present and future plastic waste, energy and environmental footprints related to COVID-19. Renew Sust Energ Rev 127:109883

Leal Filho W, Voronova V, Kloga M, Paço A, Minhas A, Salvia AL, Ferreira CD, Sivapalan S (2021) COVID-19 and waste production in households: a trend analysis. Sci Total Environ 777:145997 
Liang Y, Song Q, Wu N, Li J, Zhong Y, Zeng W (2021) Repercussions of COVID-19 pandemic on solid waste generation and management strategies. Frontiers of Environmental Science and Engineering 15: 115

Ma QX, Shan H, Zhang CM, Zhang HL, Li GM, Yang RM, Chen JM (2020) Decontamination of face masks with steam for mask reuse in fighting the pandemic COVID-19: Experimental supports. J Med Virol 92:1971-1974

Manupati VK, Ramkumar M, Baba V, Agarwal A (2021) Selection of the best healthcare waste disposal techniques during and post COVID19 pandemic era. J Clean Prod 281:125175

Mavropoulos A, Wilson D, Appelqvist B, Velis C, Cooper J (2014) Globalisation and waste management-final report from the ISWA Task Force. International Solid Waste Association (ISWA). Vienna: Austria.[Online] http://www.iswa. org/fileadmin/galleries/ Task_Forces/TFGWM_Report_GWM_LR. pdf (Accessed 30 October 2014)

Mol MPG, Caldas S (2020) Can the human coronavirus epidemic also spread through solid waste? Waste Manag Res 38:485-486

Nzeadibe TC, Ejike-Alieji AU (2020) Solid waste management during Covid-19 pandemic: policy gaps and prospects for inclusive waste governance in Nigeria. Local Environ 25:527-535

Nzediegwu C, Chang SX (2020) Improper solid waste management increases potential for COVID-19 spread in developing countries. Resour Conserv Recycl 161:104947

Okuku E, Kiteresi L, Owato G, Otieno K, Mwalugha C, Mbuche M, Gwada B, Nelson A, Chepkemboi P, Achieng Q (2021) The impacts of COVID-19 pandemic on marine litter pollution along the Kenyan Coast: a synthesis after 100 days following the first reported case in Kenya. Mar Pollut Bull 162:111840

Peng J, Wu X, Wang R, Li C, Zhang Q, Wei D (2020) Medical waste management practice during the 2019-2020 novel coronavirus pandemic: experience in a general hospital. Am J Infect Control 48: 918-921

Perkins DJ, Villescas S, Wu TH, Muller T, Bradfute S, Hurwitz I, Cheng Q, Wilcox H, Weiss M, Bartlett C (2020) COVID-19 global pandemic planning: Decontamination and reuse processes for N95 respirators. Experimental Biology and Medicine 245:933-939

Powell-Jackson T, King JJ, Makungu C, Spieker N, Woodd S, Risha P, Goodman C (2020) Infection prevention and control compliance in Tanzanian outpatient facilities: a cross-sectional study with implications for the control of COVID-19. The Lancet Global Health

Purnomo CW, Kurniawan W, Aziz M (2021) Technological review on thermochemical conversion of COVID-19-related medical wastes. Resour Conserv Recycl 167:105429

Rhee S-W (2020) Management of used personal protective equipment and wastes related to COVID-19 in South Korea. Waste Management and Research, 0734242X20933343

Rodgers RF, Lombardo C, Cerolini S, Franko DL, Omori M, Linardon J, Guillaume S, Fischer L, Fuller-Tyszkiewicz M (2021) "Waste not and stay at home" evidence of decreased food waste during the COVID-19 pandemic from the US and Italy. Appetite 160:105110

Saadat S, Rawtani D, Hussain CM (2020) Environmental perspective of COVID-19. Science of The Total Environment, 138870

Saberian M, Li J, Kilmartin-Lynch S, Boroujeni M (2021) Repurposing of COVID-19 single-use face masks for pavements base/subbase. Sci Total Environ 769:145527

Thind PS, Sareen A, Singh DD, Singh S, John S (2021) Compromising situation of India's bio-medical waste incineration units during pandemic outbreak of COVID-19: associated environmental-health impacts and mitigation measures. Environ Pollut 276:116621

Torkashvand J, Jafari AJ, Godini K, Kazemi Z, Kazemi Z, Farzadkia M (2021) Municipal solid waste management during COVID-19 pandemic: a comparison between the current activities and guidelines. J Environ Health Sci Eng. https://doi.org/10.1007/s40201-02000591-9

Tsai W-T (2021) Analysis of medical waste management and impact analysis of COVID-19 on its generation in Taiwan. Waste Management and Research, 0734242X21996803

Valizadeh J, Hafezalkotob A, Alizadeh SM, Mozafari P (2021) Hazardous infectious waste collection and government aid distribution during COVID-19: a robust mathematical leader-follower model approach. Sustain Cities Soc 69:102814

Wang J, Shen J, Ye D, Yan X, Zhang Y, Yang W, Li X, Wang J, Zhang L, Pan L (2020) Disinfection technology of hospital wastes and wastewater: suggestions for disinfection strategy during coronavirus disease 2019 (COVID-19) pandemic in China. Environmental Pollution, 114665

Wei W, Zheng D, Lei Y, Wu S, Verma V, Liu Y, Wei X, Bi J, Hu D, Han G (2020) Radiotherapy workflow and protection procedures during the coronavirus disease 2019 (COVID-19) outbreak: experience of the Hubei Cancer Hospital in Wuhan. China, Radiotherapy and Oncology

Zambrano-Monserrate MA, Ruano MA, Sanchez-Alcalde L (2020) Indirect effects of COVID-19 on the environment. Science of the Total Environment, 138813

Zand AD, Heir AV (2021a) Environmental impacts of new coronavirus outbreak in Iran with an emphasis on waste management sector. Journal of Material Cycles and Waste Management 23:240-247

Zand AD, Heir AV (2021b) Emanating challenges in urban and healthcare waste management in Isfahan, Iran after the outbreak of COVID-19. Environ Technol 42:329-336

Zhou C, Yang G, Ma S, Liu Y, Zhao Z (2021) The impact of the COVID19 pandemic on waste-to-energy and waste-to-material industry in China. Renewable and Sustainable Energy Reviews, 110693

Publisher's note Springer Nature remains neutral with regard to jurisdictional claims in published maps and institutional affiliations. 